\title{
BENCE-JONES PROTEINEMIA IN MULTIPLE MYELOMA ${ }^{1}$
}

\author{
By DAN H. MOORE, ELVIN A. KABAT, ANd ALEXANDER B. GUTMAN \\ (From the Electrophoresis Laboratory, and the Departments of Neurology and Medicine, \\ College of Physicians and Surgeons, Columbia University; the Neurological \\ Institute, and Presbyterian Hospital, New York City)
}

(Received for publication July 21, 1942)

The term "Bence-Jones protein" refers to an ill-defined group of proteins having a molecular weight of approximately 37,000 (1), and the characteristic properties of precipitating out of solution when warmed to 45 to $58^{\circ} \mathrm{C}$. and of redissolving completely or partially on boiling. This peculiar behavior on heating has long served as a useful test for Bence-Jones proteins in the urine of patients with multiple myeloma. When applied to serum, however, particularly to those sera where hyperproteinemia is associated with myeloma, the heat test has been found generally inadequate because it does not sufficiently differentiate BenceJones proteins from the serum euglobulins $(2,3)$. More convincing evidence of Bence-Jones proteinemia can be obtained by extraction (4, and others), protein solubility curves (5), and ultracentrifugation $(6,7$, and others). However, to establish satisfactorily the frequency and degree of Bence-Jones proteinemia in multiple myeloma, and its relation to hyperproteinemia in that disease, more adequate methods recently devised for characterizing proteins would appear to be necessary. Any generalizations so derived should be based upon a series of cases large enough to be representative.

In a recent study combining electrophoretic with salting-out techniques (8), it was found that 38 cases of multiple myeloma, presenting the most varied quantitative and qualitative differences in serum proteins, could be classified into 3 major groups: 1. Those with hyperglobulinemia due to $\gamma$ components which precipitated out chiefly with the Howe "euglobulin," and partly with the Howe "pseudoglobulin I" fraction. 2. Those with a variety of unusual serum protein patterns, not encountered in any other disease. 3. Those with apparently normal serum proteins. It was suggested that the protein increment in the first group

\footnotetext{
1 Aided in part by a grant from the William J. Matheson Commission.
}

contained little or no Bence-Jones protein, whereas the anomalous distributions in serum protein fractions in the second group appeared to be due, for the most part, to significant Bence-Jones proteinemia. This view was based largely upon comparisons of the solubility characteristics and electrophoretic mobilities of urinary Bence-Jones proteins with those of serum proteins in multiple myeloma, and upon a study of the properties of proteins in normal serum to which different urinary Bence-Jones proteins had been added. Further and more direct evidence on this point has since been obtained by correlating the results of salt precipitation, electrophoretic and ultracentrifugal analysis, and immunological methods in myeloma serum and urine.

\section{METHODS}

Fractional precipitation with neutral salts. Howe's method (9) was used for serum. Our results in normal and myeloma sera, and the uniform pattern in the distribution of protein fractions found in hyperproteinemia due to chronic infections and cirrhosis, have already been described (8).

Electrophoresis. The electrophoretic analyses and separations were made by means of the Tiselius apparatus (10) using a cell of $10 \mathrm{ml}$. capacity, and the Toepler Schlieren optical arrangement as modified by Longsworth (11). The samples of sera were diluted $1: 4,1: 6$, or $1: 8$ (depending upon the protein concentration) with $0.02 M$ phosphate buffer containing physiological saline solution at $\mathrm{pH} 7.4$, the ionic strength of the buffer being $\mu=0.2$. They were then dialysed against 2 or more changes of buffer for a period of 2 or 3 days, the last change of buffer being used to fill the electrode vessels. Undiluted urine samples were dialysed in the phosphate buffer ( $\mu=0.2$, not 0.1 as previously (8) stated) in the same manner and studied in the Tiselius apparatus.

Our experience with electrophoretic analyses of normal sera has been summarized elsewhere (12). Results with blood plasma or serum in multiple myeloma have been recorded by Longsworth, Shedlovsky and MacInnes (13), by Kekwick (14) and, in both serum and urine, by ourselves (8).

Ultracentrifugation. The analyses of serum and urine were made in an air-driven ultracentrifuge kindly placed 
at our disposal by Dr. A. E. Severinghaus. An analytical cell holding $0.4 \mathrm{ml}$, of the type described by Bauer and Pickels (15), was used, the optical analysis being made by means of the Toepler Schlieren method (16). The sedimentation rates were calculated from photographs taken at 5 minute intervals while the rotor was held at a constant speed of 46,400 R.P.M., giving a centrifugal field at the center of the cell of 159,000 times gravity. The experiments were done at room temperature and the sedimentation rates corrected to pure water at $20^{\circ} \mathrm{C}$.

Immunological. The general plan followed was that of Hektoen (17), with modifications. Rabbits were immunized with Bence-Jones proteins prepared from urine, the antisera were absorbed with normal human serum to remove nonspecific antibodies, and the specific antisera so obtained were used for qualitative and quantitative precipitin tests for Bence-Jones proteins in myeloma serum. To obviate difficulties arising from serological differences in the Bence-Jones proteins of different patients $(18,19)$, tests for Bence-Jones protein in serum were made with antiserum prepared only from the urinary Bence-Jones protein of that same patient. Immunological studies were confined therefore to cases of multiple myeloma with Bence-Jones proteinuria.
Our detailed procedure was as follows: Unacidified urine of the patient to be tested was treated with ammonium sulfate to 40 per cent saturation, the slight precipitate which formed was rejected, and the concentration of ammonium sulfate brought to 60 per cent to precipitate the Bence-Jones proteins. The precipitate was centrifuged off, dissolved and reprecipitated once, redissolved in water and dialysed in the cold until the dialysate no longer reacted with Nessler's solution.

Rabbits were injected 4 times weekly with 1 to $5 \mathrm{mgm}$. of this Bence-Jones protein in the form of an alum precipitate (20), several courses of 16 injections each being necessary to produce antisera of sufficient titer (even then, the best of these were much weaker than those obtainable with serum proteins or with egg albumin). The rabbits were bled 5 days after the last of a course of injections.

Antibodies to the serum proteins were removed by addition of small amounts of undiluted normal human serum until no further precipitation with normal serum occurred. The precipitin tests were set up by adding $0.15 \mathrm{ml}$. of the absorbed rabbit antiserum to $0.15 \mathrm{ml}$. of appropriate dilutions of antigen (the patient's serum or urine, control serum or urine, etc.). The tubes were shaken, incubated

TABLE I

Serum and urinary proteins in 7 cases of multiple myeloma; data obtained by the Howe method, electrophoresis, and ultracentrifugation

\begin{tabular}{|c|c|c|c|c|c|c|c|c|c|c|c|c|c|c|c|c|c|c|c|c|c|}
\hline & \multirow{3}{*}{ Case } & \multirow{3}{*}{$\begin{array}{l}\text { Sex, } \\
\text { age }\end{array}$} & \multirow{3}{*}{$\begin{array}{l}\text { Ma- } \\
\text { terial }\end{array}$} & \multicolumn{7}{|c|}{ Howe fractionation } & \multicolumn{10}{|c|}{ Electrophoretic fractionation } & \multirow{3}{*}{$\begin{array}{l}\text { Sedimentation } \\
\text { rate of main } \\
\text { component }\end{array}$} \\
\hline & & & & \multirow{2}{*}{$\begin{array}{c}\text { Total } \\
\text { protein }\end{array}$} & \multirow{2}{*}{$\underset{\text { min }}{\text { Albu- }}$} & \multirow{2}{*}{$\begin{array}{l}\text { Glob- } \\
\text { ulin }\end{array}$} & \multirow{2}{*}{$\begin{array}{c}\text { Euglob- } \\
\text { ulin }\end{array}$} & \multicolumn{3}{|c|}{ Pseudoglobulin } & \multicolumn{5}{|c|}{ Mobilities $(U \times 10)$} & \multicolumn{5}{|c|}{ Concentrations } & \\
\hline & & & & & & & & Total & I & II & $\boldsymbol{A}$ & $\boldsymbol{\alpha}$ & $\beta$ & $\mathbf{M}$ & $\boldsymbol{\gamma}$ & $\boldsymbol{A}$ & $\boldsymbol{\alpha}$ & $\boldsymbol{\beta}$ & $\boldsymbol{M}$ & $\boldsymbol{\gamma}$ & \\
\hline \multirow{4}{*}{$\overrightarrow{0}$} & & & & \multicolumn{7}{|c|}{ grams per $100 \mathrm{cc}$. serum } & & & & & & \multicolumn{5}{|c|}{$\begin{array}{l}\text { per cent lotal } \\
\text { refractioe area }\end{array}$} & $S_{\mathbf{2 0}}$ \\
\hline & & M50 & $\underset{\text { Srine }}{\text { Serum }}$ & $\begin{array}{r}13.6 \\
0.5\end{array}$ & 3.6 & 10.0 & 7.2 & 2.8 & 2.0 & 0.8 & $\begin{array}{l}5.2 \\
5.4\end{array}$ & 3.6 & 2.9 & 1.6 & 0.5 & $\begin{array}{r}26 \\
5\end{array}$ & 5 & 9 & 95 & 60 & $\begin{array}{l}7.1 \\
3.4\end{array}$ \\
\hline & 39 & M61 & $\begin{array}{l}\text { Serum } \\
\text { Urine }\end{array}$ & $\begin{array}{r}13.1 \\
1.7\end{array}$ & 3.1 & 10.0 & 5.4 & 4.6 & & & $\begin{array}{l}4.7 \\
5.0\end{array}$ & 3.4 & 2.6 & 1.4 & 0.3 & $\begin{array}{r}20 \\
5\end{array}$ & 4 & 5 & 95 & 71 & $\begin{array}{l}7.1 \\
3.4\end{array}$ \\
\hline & 40 & M84 & $\begin{array}{l}\text { Serum } \\
\text { Urine }\end{array}$ & $\begin{array}{c}9.6 \\
\text { Trace }\end{array}$ & 2.6 & 7.0 & 5.4 & 1.6 & 0.8 & 0.8 & 5.0 & 3.6 & 2.6 & 1.4 & $0.7 \mid$ & 31 & 8 & 7 & 51 & 3 & 6.5 \\
\hline \multirow{3}{*}{$\begin{array}{l}\text { Na } \\
\text { ò } \\
\text { ปे }\end{array}$} & & M63 & $\begin{array}{l}\text { Serum } \\
\text { Urine }\end{array}$ & $\begin{array}{l}8.1 \\
0.9\end{array}$ & 6.0 & 2.1 & 0.1 & 2.0 & & & $\begin{array}{l}5.4 \\
5.4\end{array}$ & 3.5 & $\begin{array}{l}2.8 \\
2.8\end{array}$ & 1.6 & 0.5 & $\begin{array}{r}40 \\
5\end{array}$ & 5 & $\begin{array}{l}13 \\
95\end{array}$ & 36 & 6 & $\begin{array}{l}4.0 \\
2.8\end{array}$ \\
\hline & 41 & M73 & $\begin{array}{l}\text { Serum } \\
\text { Urine }\end{array}$ & $\begin{array}{l}5.3 \\
0.0\end{array}$ & 1.7 & 3.6 & 0.2 & 3.4 & 1.6 & 1.8 & 5.1 & 3.4 & 2.6 & & 1.0 & 29 & 23 & 33 & & 15 & 3.0 \\
\hline & 42 & F52 & $\begin{array}{l}\text { Serum } \\
\text { Urine }\end{array}$ & $\begin{array}{r}10.5 \\
0.0\end{array}$ & 2.9 & 7.6 & 0.3 & 7.3 & 0.8 & 6.5 & 5.4 & 3.3 & 2.5 & 1.7 & 0.1 & 22 & 10 & 18 & 46 & 4 & 7.0 \\
\hline $\begin{array}{l}m \\
\text { o. } \\
\text { ㅎํ }\end{array}$ & 43 & M51 & $\begin{array}{l}\text { Serum } \\
\text { Urine }\end{array}$ & $\begin{array}{l}5.5 \\
1.9\end{array}$ & 4.2 & 1.3 & 0.1 & 1.2 & 0.7 & 0.5 & $\begin{array}{l}5.4 \\
5.1\end{array}$ & 3.7 & $\begin{array}{l}2.6 \\
2.4\end{array}$ & & & $\begin{array}{r}68 \\
5\end{array}$ & 10 & $\begin{array}{l}17 \\
95\end{array}$ & & 5 & 3.4 \\
\hline
\end{tabular}

Cases 1 and 11 were reported in part elsewhere (8), the electrophoretic patterns and data in Case 11 there given having been obtained with barbiturate buffer of lesser ionic strength.

The electrophoretic component " $M$ " refers to an extra boundary appearing between the $\beta$ and $\gamma$ components in the serum and in the urine of many cases of multiple myeloma.

The sedimentation constants in the last column refer to electrophoretically separated components (see text). 

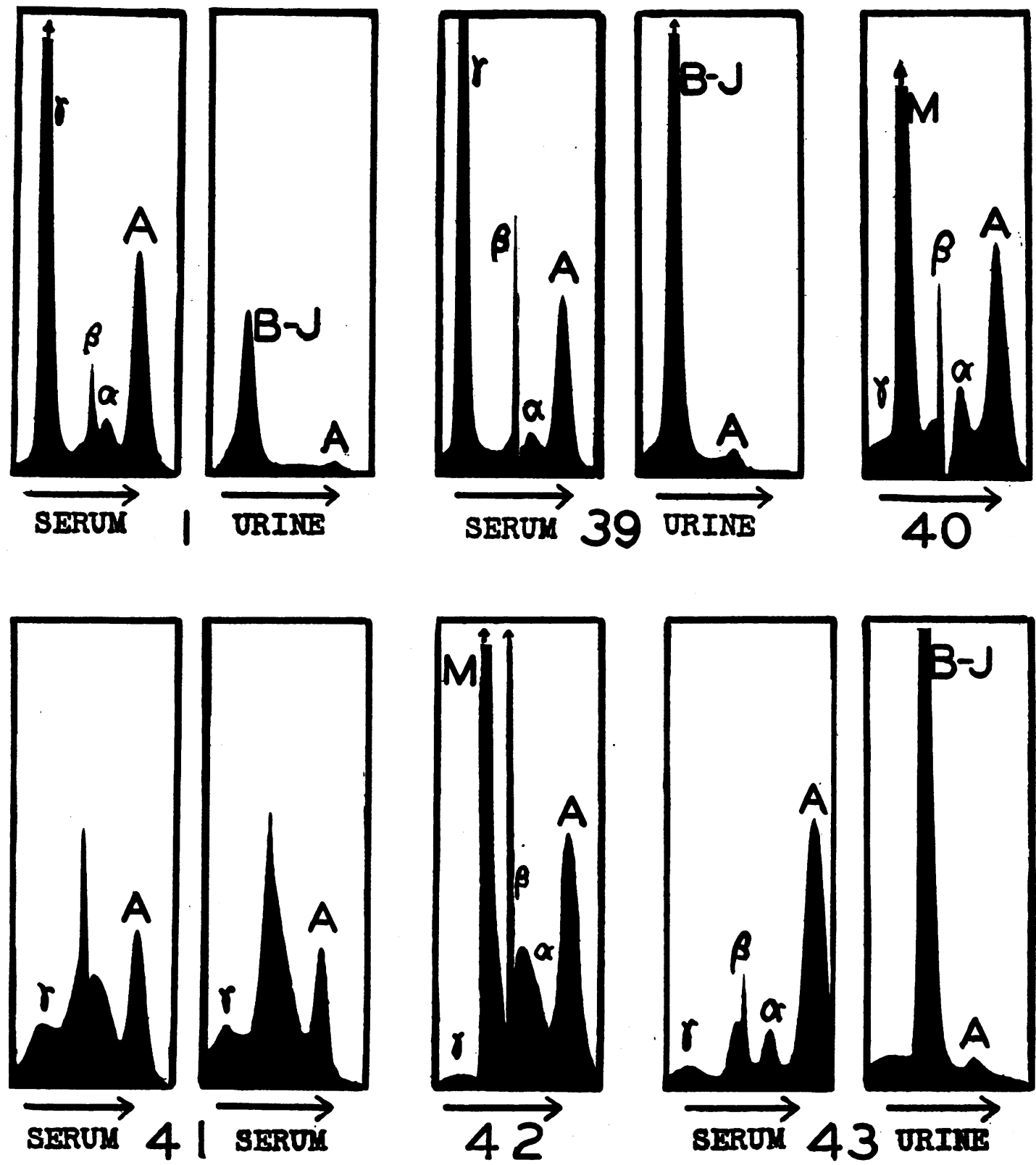

Fig. 1. Electrophoretic Patterns (descending limb) in Sera and Urine in 6 Cases of Multiple Myeloma

In Case 41, the pattern on the left was obtained before extraction of lipids, that on the right, after extraction. The pattern in Case 11 was given elsewhere (8).

at $37^{\circ} \mathrm{C}$. for 2 hours, and allowed to stand overnight in the ice-box. Readings were then made in the usual manner. The amount of Bence-Jones protein present in the serum tested could be estimated roughly from the maximal dilution of antigen which still gave a precipitate. More accurate estimates were made by applying the quantitative precipitin method of Goettsch and Kendall (21). A curve was constructed representing the nitrogen content of washed precipitates obtained by adding known amounts of purified Bence-Jones protein to. measured volumes of rabbit antiserum. From this curve, by adding an appropriate amount of an unknown sample to the same volume of serum, and determining the nitrogen content of the washed precipitate, the amount of Bence-Jones protein present in unknown mixtures, such as myeloma serum, could be estimated. 


\section{RESULTS}

In Table I are summarized the results of serum protein partitions by the Howe and electrophoretic techniques in 7 cases of multiple myeloma. The diagnosis was established by autopsy or biopsy in all but Case 41 . The cases are divided into the 3 major groups already described.

Group 1. The serum protein pattern in Cases 1 and 39 is representative of that found in a large number of patients with multiple myeloma. There is marked hyperproteinemia, the protein increment being composed of globulins, the major part of which are thrown down in 13.5 per cent sodium sulfate. The electrophoretic pattern is characterized by a large peak representing a marked increase in $\gamma$ globulins (Figure 1), the mobilities of the main component in these 2 cases being 0.5 and 0.3 respectively.

The following evidence that the protein increment in this group of cases includes little or no Bence-Jones proteins has already been offered: 1 . The distribution of serum protein fractions corresponds, in general, to the pattern uniformly found in hyperglobulinemia due to chronic infections or cirrhosis, in which it may be presumed that BenceJones proteinemia does not occur. 2. Bence-Jones proteins in native urine rarely if ever have the solubility characteristics of serum euglobulins in either ammonium or sodium sulfate solution. 3 . We have been unable to reproduce a large increase wholly or very largely in the Howe "euglobulin" fraction by adding various urinary Bence-Jones protein preparations to normal serum. 4. The electrophoretic pattern of normal serum, to which has been added urinary Bence-Jones protein from patients in this group, shows a new peak corresponding to the mobility of the urinary BenceJones protein added, but not in the $\gamma$ range (except in the few instances in which the mobility of the urinary Bence-Jones protein is extremely low).

When the $\gamma$ components of the sera in Cases 1 and 39 were separated electrophoretically and their sedimentation constants determined, the value obtained for $S_{20}$ was 7.1 in both instances (Table I). The sedimentation constant of the urinary Bence-Jones proteins in both patients was $3.4 S$ (Svedberg (22) reports values of $2.8 S$ and $3.7 S$ in different Bence-Jones protein preparations). It is evident that the main component in the sera was

TABLE II

Precipitin reactions of absorbed rabbit antisera to Bence-Jones, proteins with homologous urines and sera, and with normal sera

\begin{tabular}{|c|c|c|c|c|c|c|c|c|}
\hline \multicolumn{4}{|c|}{ Case I } & \multicolumn{5}{|c|}{ Case II } \\
\hline Antigen & Dilution & $\begin{array}{c}R_{22} \text { absorbed } \\
\text { with normal } \\
\text { human } \\
\text { serum }\end{array}$ & Saline & Antigen & Dilution & $\begin{array}{l}R_{27} \text { absorbed } \\
\text { with normal } \\
\text { human } \\
\text { serum }\end{array}$ & $\begin{array}{c}R_{27} \text { absorbed } \\
\text { with Case } 11 \\
\text { serum }\end{array}$ & Saline \\
\hline $\begin{array}{l}\text { Bence-Jones } \\
\text { protein }\end{array}$ & $1: 10,000$ & $+t+$ & - & $\begin{array}{l}\text { Bence-Jones } \\
\text { protein }\end{array}$ & $1: 10,000$ & $++t$ & - & - \\
\hline Case 1 , urine & $\begin{array}{l}1: 10 \\
1: 100 \\
1: 1000\end{array}$ & $\begin{array}{r}++++ \\
+ \\
\pm\end{array}$ & $\begin{array}{l}- \\
- \\
-\end{array}$ & Case 11 , urine & $\begin{array}{l:l}1: 10 \\
1: 25 \\
1: 100 \\
1: 125 \\
1: 1000\end{array}$ & $\begin{array}{r}\bar{t} \\
++ \pm \\
++ \pm \\
\pm\end{array}$ & - & $\begin{array}{l}- \\
\overline{-} \\
-\end{array}$ \\
\hline Case 1 , serum & $\begin{array}{l}\text { Undil. } \\
1: 5 \\
1: 25 \\
1: 125\end{array}$ & $\begin{array}{r}\overline{+} \\
+\frac{ \pm}{+}\end{array}$ & $\begin{array}{l}- \\
\bar{z}\end{array}$ & Case 11 , serum & $\begin{array}{l:l}1: 25 \\
1: 125 \\
1: 625\end{array}$ & 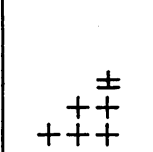 & $-*$ & $\bar{z}$ \\
\hline $\begin{array}{l}\text { Normal human } \\
\text { serum }\end{array}$ & $\begin{array}{l}\text { Undil. } \\
1: 5 \\
1: 25 \\
1: 125\end{array}$ & $\begin{array}{l}- \\
-\end{array}$ & $\begin{array}{l}- \\
\overline{-}\end{array}$ & $\begin{array}{l}\text { Normal human } \\
\text { serum }\end{array}$ & $\begin{array}{l:l}1 & : 25 \\
1 & : 125 \\
1 & : 625\end{array}$ & $\bar{z}$ & & $\overline{-}$ \\
\hline Saline & & - & & Saline & & - & & \\
\hline
\end{tabular}

* $1: 500$ dilution. 
of far greater molecular size than Bence-Jones protein, of the order of magnitude of normal $\gamma$ globulins, which have been found to have a sedimentation constant of $7.1 S$ (23). Similar results were obtained in 4 of 5 myeloma sera subjected to ultracentrifugal analysis by Kekwick (14), and in isolated cases by others. The available data suggest that Bence-Jones protein does not constitute the main protein increment in the majority of cases of multiple myeloma with marked hyperproteinemia.

While it was thus shown that the chief protein constituent of these sera was not Bence-Jones protein, it was possible by serological methods to demonstrate that Bence-Jones protein was present in small amount in the serum of Case 1. As indicated in Table II, rabbit antiserum to this patient's urinary Bence-Jones protein gave a strong precipitin reaction with a $1: 25$ dilution of the patient's serum, and a definite reaction was obtainable with a dilution of $1: 125$. These reactions cannot be attributed to normal serum protein components because normal serum failed to give any test with the (absorbed) antiserum.

It was further possible, by serological methods, to estimate the amount of Bence-Jones protein present in the serum of Case 1 . Figure 2 shows the calibration curve obtained by the addition of increasing amounts of Bence-Jones protein $\mathrm{N}$ to $1.0 \mathrm{ml}$. of rabbit antiserum. When $1.0 \mathrm{ml}$. and $2.0 \mathrm{ml}$. of a $1: 25$ dilution of the serum of Case 1 were added, the $\mathrm{N}$ contents of the precipitates (points $\mathrm{A}$ and $\mathrm{B}$, respectively, on the curve) corresponded to 0.013 and $0.019 \mathrm{mgm}$. of BenceJones protein $\mathrm{N}$. Assuming a conversion factor of 6.25 , this is the equivalent of 0.2 and 0.15 gram Bence-Jones protein per $100 \mathrm{ml}$. undiluted serum. It is obvious that this concentration of BenceJones protein, some 1.5 per cent of the total protein content of the serum, could not be detected by ultracentrifugal or electrophoretic methods.

Case 40 differs from the other members of Group 1. While the Howe partition showed marked hyperglobulinemia due to a large increase in the "euglobulin" fraction, electrophoretic analysis revealed the mobility of this component to be 1.4 , considerably above the upper limits of variation in $\gamma$ globulins (12). The sedimentation constant of the electrophoretically separated $\mathbf{M}$ and $\gamma$ com-

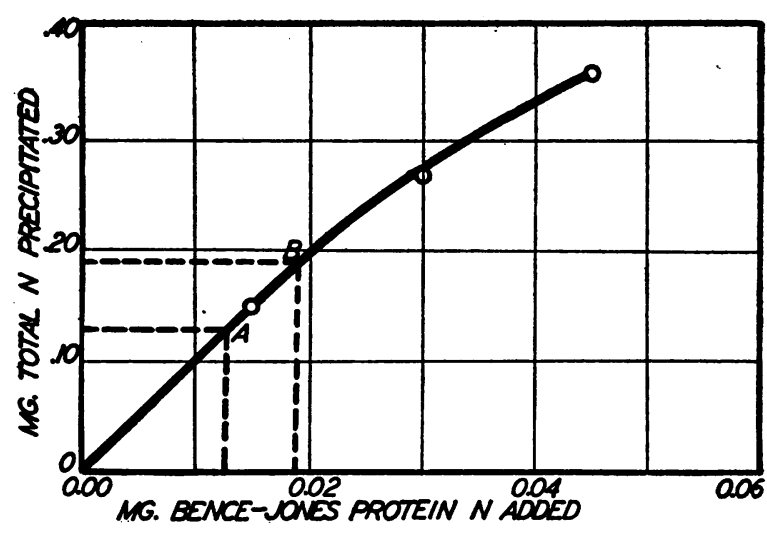

Fig. 2. Calibration Curve for the Determination of Bence-Jones Protein in Serum by the Quantitative Precipitin Method

A blank value of $0.02 \mathrm{mgm}$. N per ml. serum without added antigen was obtained and substracted.

All supernatants tested show a zone in which addition of either antigen or antibody gave some additional precipitation. This suggests the presence of several immunologically different components and may be related to the observation of Hektoen and Welker (19) that 2 serologically distinct Bence-Jones proteins may occur in the urine of a single patient.

ponents was found to be $6.5 S$ (Table I). This value would indicate a molecular size far greater than that of Bence-Jones protein, at least if uncombined with other constituents. The main protein component of the serum in Case 40 was not further identified, and the classification of the case in Group 1 is tentative.

Group 2. The serum protein patterns in this group are varied, but fall into certain distinct categories (8): 1. Due to the presence of abnormal protein constituents which (like serum albumin) are soluble in 21.5 per cent sodium sulfate, the values for albumin, as determined by the usual Howe technique, may be falsely high; if the concentration of these constituents is sufficiently great, the results of salt precipitation may seem to indicate distinct hyperalbuminemia. 2. The Howe globulin fraction may be markedly increased, due solely to a rise in the fraction precipitable in 17.4 per cent sodium sulfate (the Howe "pseudoglobulin I" fraction) with no accompanying rise in the Howe "euglobulin" fraction. 3. The fraction precipitable in 21.5 per cent sodium sulfate may greatly exceed the normal maximum, with hyperglobulinemia due partly or solely to protein constituents having solubility characteristics corre- 
sponding with those of the Howe "pseudoglobulin II" fraction.

The electrophoretic patterns in this group, likewise varied, indicate the presence of abnormal components with the mobility of $\beta$ globulins, of $\gamma$ globulins, or with intermediate mobilities forming a distinct intermediate boundary which we have designated as $M$.

The following considerations led us to suggest that these different serum protein patterns may be due, for the most part, to the presence of significant concentrations of Bence-Jones proteins, characterized by different solubilities in sodium sulfate and by different electrophoretic mobilities (8): 1 . The several patterns are peculiar to multiple myeloma, the only disease in which significant BenceJones proteinemia may be presumed to occur. 2 . The solubilities of urinary Bence-Jones proteins in sodium sulfate solution vary widely in different cases of multiple myeloma, but generally fall within the precipitation limits prescribed by Howe for serum albumins and pseudoglobulins I and II. 3. Addition of urine containing Bence-Jones protein to normal serum results in large increases chiefly in the Howe albumin, "pseudoglobulin II" or "pseudoglobulin I" fraction, depending upon the particular urine added. The inference seems justified that if such Bence-Jones proteins were present in the serum of myeloma patients and the same solubilities with respect to sodium sulfate were shown, the various Howe serum protein partitions included in Group II could result. 4. The electrophoretic mobilities of urinary Bence-Jones proteins from different patients differ widely, from 3.1 to 1.8 in the cases we have examined, i.e., over the range observed in the mobilities of the extra components encountered in myeloma sera. 5. The electrophoretic patterns of normal serum to which urinary Bence-Jones proteins have been added show new $\beta, \gamma$, or M peaks, according to the mobility of the particular Bence-Jones protein added. It was possible in this way to reproduce the several electrophoretic patterns characteristic of Group 2; by adding the urinary Bence-Jones protein of a given patient to normal serum, the electrophoretic pattern of that patient's serum could be duplicated (8).

Case 11 is an example of apparent hyperalbuminemia in multiple myeloma (Table I). Corre- lation of the results of analyses by salting-out, electrophoretic, and precipitin techniques indicated that the Howe values for albumin in this case were much too high, owing to the presence of about 2.0 grams per cent of a protein with the solubility characteristics and electrophoretic mobility of the Bence-Jones protein in this patient's urine (8).

The $\beta$ and $\gamma$ components of the serum in Case 11 were separated electrophoretically from the $\alpha$ globulins and albumin, and the sedimentation constant determined. ${ }^{2}$ The value obtained for the main component in the ultracentrifuge, $4.0 \mathrm{~S}$, cannot refer to serum albumins, which had been removed electrophoretically, and indicates a molecular size definitely smaller than that of any serum globulin. The sedimentation constant of the Bence-Jones protein in the urine of Case 11 was $2.8 S$.

That the main abnormal component of the serum in Case 11 was, in fact, Bence-Jones protein in some form, could be demonstrated by serological methods (Table II). Rabbit antiserum to this patient's urinary Bence-Jones protein gave a strong precipitin reaction with a 1:625 dilution of the patient's serum. This reaction appeared to be due entirely to Bence-Jones protein since, after absorption of the rabbit antiserum with Case 11 myeloma serum, no additional precipitin reaction could be obtained with the patient's urine or purified BenceJones protein (Table II) ; nor did the (absorbed) antiserum react with normal serum protein components. Estimation of the concentration of Bence-Jones protein in the serum, by means of qualitative dilution tests, gave results of the same order of magnitude as were obtained for the main

\footnotetext{
2 The separated fraction of Case 11, which included a small amount of normal $\boldsymbol{\gamma}$ globulin and an unknown amount of normal $\boldsymbol{\beta}$ globulin, showed a small, very heavy component $(S=20)$ but only one boundary in the range where globulins and Bence-Jones protein would be expected. The precision of the sedimentation constant determination for the lighter fractions would thus be reduced, the resulting value tending to be high for whatever BenceJones protein was present. Electrophoretic separation of the $\boldsymbol{\gamma}$ globulin in this fraction (only about 6 per cent, of which at least half was due to the salt boundary) was not possible because of the limited quantity of material available. Separation of Bence-Jones protein from $\beta$ globulin in this serum would not be possible electrophoretically.
} 
abnormal component by other methods. Quantitative precipitin determinations could not be made in this case because of the weak rabbit antisera produced and the limited amounts of urinary Bence-Jones protein available.

Case 41 showed moderate hyperglobulinemia, due to protein constituents which had the solubility characteristics in sodium sulfate of Howe's "pseudoglobulin II" fraction (Table I). The electrophoretic pattern revealed a large component moving with the mobility of $\beta$ globulin (Figure 1 ). To eliminate the possibility that this might be a lipoidal substance, the serum was extracted with alcohol-ether mixture at $-12^{\circ}(24)$. The resulting electrophoretic pattern showed no significant change (Figure 1). The cholesterol content of the serum did not exceed $118 \mathrm{mgm}$. per cent.

The $\beta$ and $\gamma$ components of the serum in case 41 were separated out electrophoretically and the sedimentation constant determined to be $3.0 \mathrm{~S}$, a figure subject to the limits in precision already indicated. This value is consistent with a protein of the molecular size of Bence-Jones protein.

No Bence-Jones protein was found in the urine of Case 41 on repeated examination. The absence of Bence-Jones proteinuria in this patient with Bence-Jones proteinemia suggests that the serum Bence-Jones protein might have been present in the circulating fluids in the form of some complex. Bott and Richards (25) have shown that the "intact" amphibian glomerular membrane is partially permeable to proteins of Svedberg's 35,200 molecular weight group; in the case of several BenceJones preparations tested, the glomerular filtration values were 20 to 48 per cent. It is likely that the maximal pore diameter of the "intact" human glomerular membrane is similarly sufficient for partial passage of uncombined Bence-Jones protein in serum, since Bence-Jones proteinuria without significant albuminuria is commonly observed. If so, the absence of Bence-Jones protein in the urine of patients who give evidence of appreciable concentrations in the serum, and who have normally permeable glomerular membranes (no marked nitrogen retention), would imply that the Bence-Jones protein might occur in the serum in complexes of larger molecular size.

In the course of certain routine determinations in the serum of Case 41, it was observed that although the serum itself was clear, the trichloroacetic acid filtrates obtained were cloudy, due to the presence of a substance which could not be removed by multiple filtration. (This phenomenon indeed gave the first intimation of anything unusual about the then undiagnosed case.) It developed that if undiluted serum were used, perfectly clear filtrates could be obtained with either tungstic or trichloroacetic acids; whereas, if the serum were first brought to the usual dilutions with water, none of the common protein precipitation gave clear filtrates. This unusual behavior would not be inconsistent with the presence of a complex dissociable on dilution. The extreme lability of this complex precluded its further study in an undissociated state.

The serum in Case 42 is unique in our experience. It contained very large amounts of a globulin which precipitated out with the Howe "pseudoglobulin II" fraction and which, migrating with the mobility of 1.7 , produced an $M$ peak intermediate between the $\beta$ and $\gamma$ components. The sedimentation constant of the electrophoretically separated $\mathrm{M}$ and $\boldsymbol{\gamma}$ components however was 7.0 S, indicating a molecular size of normal $\gamma$ globulins. Further studies of this constituent of the serum in Case 42 have been carried out by Shapiro, Ross, and Moore (26). The main component of the serum in this instance was clearly not Bence-Jones protein and the classification of Case 42 in Group 2 is tentative.

Group 3. Case 43 presented normal Howe and electrophoretic serum protein patterns (Table I) and is representative of the large number of cases of multiple myeloma that show no abnormalities when studied by these methods. The urine in Case 43 contained large amounts of a Bence-Jones protein which was found to have a sedimentation constant of $3.4 S$.

It was pointed out elsewhere (8) that some myeloma sera with normal Howe partitions may show abnormal electrophoretic patterns, characterized by a small $M$ peak, presumably due to Bence-Jones proteinemia. Immunological studies, which might disclose further evidences of BenceJones proteinemia in apparently normal myeloma sera, have not yet been made. 


\section{DISCUSSION}

Bence-Jones proteins evidently must be present in the serum of at least those cases of multiple myeloma with Bence-Jones proteinuria, since, in the absence of any indication of a renal origin, the Bence-Jones protein must be transported by the blood from the source of origin to the kidneys. Even in cases with no excretion in the urine, the possibility of significant Bence-Jones proteinemia is not excluded, because interaction in the serum may result in the formation of non-filterable complexes. The problem therefore is not so much to determine whether Bence-Jones proteinemia ever occurs in myeloma, as to devise methods adequate for its detection and measurement.

A major difficulty in the way of this objective lies in the multiplicity of Bence-Jones proteins $(18,19,22,27,28)$ and in their correspondingly varied properties, as illustrated by the differences in solubility, electrophoretic mobility, sedimentation rate, and serological properties observed in the urinary Bence-Jones proteins in our cases of myeloma ( 8 , and the present study). These differences, reflected in the varied serum protein patterns of patients with Bence-Jones proteinemia, necessitate a broad and flexible analytical approach. This is particularly true in view of added difficulties due to the presence in myeloma serum of normal and abnormal proteins, usually in great excess, to the probable formation of various more or less labile complexes or combinations in some cases, and to a variety of other causes.

It would appear, nevertheless, that the problem is not beyond the reach of integrated studies by salting-out, electrophoretic, and ultracentrifugal methods, supplemented by the quantitative precipitin technique. Such, at least, is the indication of the preliminary results recorded here.

With regard to the proposed classification of serum protein patterns in multiple myeloma (8), the present data support its general validity and usefulness. It need hardly be pointed out that the classification falls far short of the ideal analysis into homogenous components, and that it is incomplete. Too little is known about the occurrence in myeloma serum of abnormal proteins other than Bence-Jones protein, however, to warrant further subdivision at this time.

\section{SUMMARY}

The serum and urinary proteins in 7 cases of multiple myeloma were investigated by correlated salting-out, electrophoretic, and ultracentrifugal techniques, supplemented by immunological methods in 2 cases.

In 2 cases with marked hyperglobulinemia due to $\gamma$ components which precipitated out chiefly with the Howe "euglobulin" fraction, sedimentation constants of the main component of the serum indicated a molecular size of the order of magnitude of normal $\gamma$ globulins. Application of the quantitative precipitin technique to the serum of one of these cases further revealed the presence of approximately 0.2 gram per cent Bence-Jones protein, a concentration too low for detection by other methods. A review of the available data indicates that only a very small proportion of the protein increment is Bence-Jones protein in many (probably the majority of) cases of multiple myeloma with marked hyperproteinemia.

Two cases with sera showing abnormal $\beta$ or $\mathrm{M}$ components, and unusual Howe partitions not encountered in diseases other than multiple myeloma, were found by ultracentrifugal and serological analysis to have Bence-Jones protein as the chief abnormal protein component of the serum. The available data suggest that marked BenceJones proteinemia does occur in multiple myeloma, probably in a lesser but clinically significant proportion of cases.

Two cases of multiple myeloma with marked hyperproteinemia were found to have large concentrations of abnormal, not readily classifiable proteins with sedimentation constants indicating an approximate molecular size of normal globulins. The serum in one case of multiple myeloma was found to have apparently normal Howe and electrophoretic serum protein patterns.

In spite of the difficulties involved in the detection and measurement of Bence-Jones proteins in serum, integrated studies of the kind indicated appear to afford a promising approach to the problem.

\section{BIBLIOGRAPHY}

1. Bull, H. B., Protein structure. Advances in Enzymol., 1941, 1, 1.

2. Perlzweig, W. A., Delrue, G., and Geschickter, C., 
Hyperproteinemia associated with multiple myelomas. J. A. M. A., 1928, 90, 755.

3. Magnus-Levy, A., Multiple Myelome. VII. Euglobulinämie. Zur Klinik und Pathologie. Amyloidosis. Ztschr. f. klin. Med., 1933, 126, 62.

4. Cantarow, A., Bence-Jones proteinemia in multiple myeloma. Am. J. M. Sc., 1935, 189, 425.

5. Kydd, D. M., Bence-Jones protein in serum. J. Biol. Chem., 1934, 107, 747.

6. McFarlane, A. S., The behaviour of pathological sera in the ultracentrifuge. Biochem. J., 1935, 29, 1175.

7. Packalen, T., A case of myeloma with spontaneously crystallizing protein in blood serum and urine. Acta med. Scandinav., 1939, 100, 1.

8. Gutman, A. B., Moore, D. H., Gutman, E. B., McClellan, V., and Kabat, E. A., Fractionation of serum proteins in hyperproteinemia, with special reference to multiple myeloma. J. Clin. Invest., 1941, 20, 765.

9. Howe, P. E., The determination of proteins in blooda micro method. J. Biol. Chem., 1921, 49, 109.

10. Tiselius, A., A new apparatus for electrophoretic analysis of colloidal mixtures. Trans. Faraday Soc., 1937, 33, 524.

11. Longsworth, L. G., A modification of the Schlieren method for use in electrophoretic analysis. J. Am. Chem. Soc., 1939, 61, 529.

12. Moore, D. H., and Lynn, J., Electrophoretic measurements on normal human plasma. J. Biol. Chem., 1941, 141, 819.

13. Longsworth, L. G., Shedlovsky, T., and MacInnes, D. A., Electrophoretic patterns of normal and pathological human blood serum and plasma. J. Exper. Med., 1939, 70, 399.

14. Kekwick, R. A., The serum proteins in multiple myelomatosis. Biochem. J., 1940, 34, 1248.

15. Bauer, J. H., and Pickels, E. G., An improved airdriven type of ultracentrifuge for molecular sedimentation. J. Exper. Med., 1937, 65, 565.
16. Chiles, J. A., and Severinghaus, A. E., Hormone studies with the ultracentrifuge. III. An application of Toepler's Schlieren method to the analytical ultracentrifuge. Rev. Scientific Instruments, 1940, $11,71$.

17. Hektoen, L., Specific precipitin for Bence-Jones protein. J. A. M. A., 1921, 76, 929.

18. Bayne-Jones, S., and Wilson, D. W., Immunological reactions of Bence-Jones proteins. II. Differences between Bence-Jones proteins from various sources. Bull. Johns Hopkins Hosp., 1922, 33, 119.

19. Hektoen, L., and Welker, W. H., Immunological differences of crystalline Bence-Jones proteins. Biochem. J., 1940, 34, 487.

20. Heidelberger, M., and Kendall, F. E., A quantitative theory of the precipitin reaction. III. The reaction between crystalline egg albumin and its homologous antibody. J. Exper. Med., 1935, 62, 697.

21. Goettsch, E., and Kendall, F. E., Analysis of albumin and globulin in biological fluids by the quantitative precipitin method. J. Biol. Chem., 1935, 109, 221.

22. Svedberg, T., and Pederson, K. O., The Ultracentrifuge. Clarendon Press, Oxford, 1940.

23. Kabat, E. A., The molecular weight of antibodies. J. Exper. Med., 1939, 69, 103.

24. Wu, H., Effect of removal of lipoids on precipitability of serum proteins by neutral salts. Chinese J. Physiol., 1933, 7, 125.

25. Bott, P. A., and Richards, A. N., The passage of protein molecules through the glomerular membranes. J. Biol. Chem., 1941, 141, 291.

26. Shapiro, S., Ross, V., and Moore, D. H., A viscous protein obtained in large amount from the serum of a patient with multiple myeloma. J. Clin. Invest. (In press.)

27. Magnus-Levy, A., Utber krystallisiertes und amorphes Bence-Jones Eiweiss. Multiple Myelome. Ztșchr. f. physiol. Chem., 1936, 243, 173.

28. Devine, J., An analysis of Bence-Jones protein. Biochem. J., 1941, 35, 433. 